\title{
Commentary: Single-ventricle reconstruction: Chronicle of a death foretold?
}

\author{
Emile A. Bacha, MD
}

\footnotetext{
From the Division of Cardiac, Thoracic and Vascular Surgery, Department of Pediatric and Congenital Cardiac Surgery, New York-Presbyterian/Morgan Stanley Children's Hospital, Columbia University Medical Center, New York, NY.

Disclosures: Author has nothing to disclose with regard to commercial support.

Received for publication Feb 2, 2019; accepted for publication Feb 4, 2019; available ahead of print April 13 , 2019.

Address for reprints: Emile A. Bacha, MD, Department of Cardiac Surgery, Columbia University, Morgan Stanley Children's Hospital, Columbia University Medical Center, New York, NY 10032 (E-mail: eb2709@cumc. columbia.edu).

J Thorac Cardiovasc Surg 2019;158:843-4

0022-5223/\$36.00

Copyright (C) 2019 by The American Association for Thoracic Surgery

https://doi.org/10.1016/j.jtcvs.2019.02.119
}

\section{De leur meilleur côté tâchons de voir les choses: \\ Vous vous plaignez de voir les rosiers épineux; \\ Moi je me réjouis et rends grâces aux dieux \\ Que les épines aient des roses.}

[Let us see things on their best side: You complain of seeing roses that have thorns; I rejoice and give thanks to the gods that the thorns have roses.]

-Alphonse Karr (Sur la Plage, 1862)

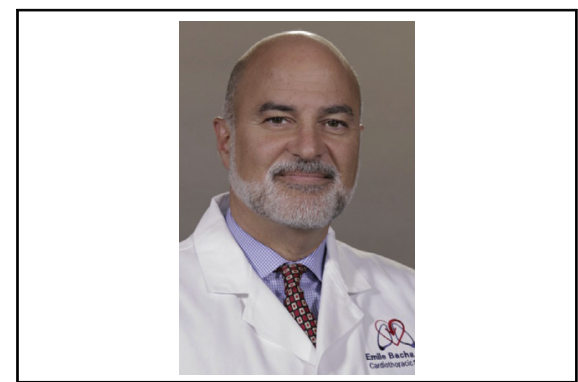

Emile A. Bacha, MD

Central Message

Hypoplastic left heart syndrome has been studied extensively. Much progress has been made but much more remains to do to improve long-term outcomes.

See Editorial page 837
Hypoplastic left heart syndrome (HLHS), a source of lifelong pain and suffering for patients and their families and a source of so much work, heartache, and headaches for medical providers, has been studied in more detail perhaps than any other serious congenital heart malformation. In their review in this issue of the Journal, Karamlou and colleagues ${ }^{1}$ focus on many scientific aspects of recent investigations on HLHS, most importantly the follow-up studies stemming from the original Single Ventricle Trial. ${ }^{2}$ The themes they approach can be classified in 4 main items, each worthy of extensive discussion beyond the reach of this editorial.

Karamlou and colleagues ${ }^{1}$ note the sobering reality of 5 -year survival results in the range of $60 \%$. Despite some individual centers' reporting of better results, the "serious" longitudinal studies stemming from individual centers report the same range. ${ }^{3}$ The prevalences of serious neurologic events and of thrombotic events among these survivors were $20 \%$ and $16 \%$, respectively. Exercise performance decreases relentlessly after the Fontan operation. ${ }^{4}$ A sobering landscape indeed.

Karamlou and colleagues ${ }^{1}$ focus on the tremendous variability of practice across centers, and they note that much could be learned from "best performers" and that the lack of standardized definitions for complications hampers such progress, both of which statements I wholeheartedly agree with. Although a few initiatives, such as the early extubation project, ${ }^{5,6}$ the National Pediatric Cardiology Quality Improvement Collaborative "learning from others" program, ${ }^{7}$ the Residual Lesion Study, and the Congenital Heart Technical Skill Study, ${ }^{9}$ do reach out across silos, the reality is that most centers rely on antiquated and ineffective methods of expansion of knowledge, such as journals, meetings, and presentations. We have to be thinking about more effective ways to spread and share knowledge and best practices.

Interestingly, Karamlou and colleagues ${ }^{1}$ also plausibly argue for changing the time-honored transplant-free 1-year survival metric to a simpler 1-year survival, with or without transplant. Indeed, although this is a philosophical shift as much as a pragmatic one (for example, the cost of longterm Fontan care is higher than that of heart transplantation, ${ }^{10}$ it makes a lot of sense. A heart transplant performed during palliation for HLHS need not be a mark of failure; indeed, one could argue that it is sometimes unavoidable, and that the best teams are able to manage their patients adroitly toward a transplant in a deliberate and proactive fashion. The classification of a patient with HLHS who undergoes transplant as representing failure of palliation strategy (according to Single Ventricle Trial definition) or success of overall treatment (according to parental, patient, and societal definition) is itself worthy of a longer discussion. It has been 
suggested that single-ventricle palliation is simply a bridge to transplant, and any treatment strategy that results in a viable candidate for transplant (or, in the not too distant future, durable mechanical support or xenotransplantation) should probably not be judged as simply a "failure."

Karamlou and colleagues ${ }^{1}$ briefly address the surgeonvolume and the center-volume outcome relationships, where common sense and a plethora of data support highvolume surgeons and centers for best outcomes. Naturally, in this context, the issue of regionalization of care for the Norwood procedure is also discussed. They point to the California, Sweden, and UK experiences as examples where regionalization has resulted in improved outcomes. They also point out that although these are seductive (but supported) theories, implementation within the complicated US health care system is challenging. This is truly the "third rail" of congenital heart care. No one wants to touch it, for reasons that have nothing to do with patient care or medical science. Ego, pride, academic prestige, politics, money, and the complexity of the US health care system result in complacency and inaction. ${ }^{11}$ Regionalization and optimization of concentrated experience would be, in my opinion, the most effective and fastest way to improve outcomes. Unfortunately, it is also the most difficult to achieve. Our successors may one day be looking back at our failure to do the right thing for our patients.

Karamlou and colleagues ${ }^{1}$ close on a fairly pessimistic note. They note that although early survival has dramatically increased, excellent long-term outcomes "remain elusive," and they conclude that the end of the story "is still unknown."

I would argue that the end of the current story is known. The current story is one of significant hardship for patients and families, that ends inevitably, at some point in time, sometimes early and sometimes late (the success stories), in heart or heart-liver transplantation, early demise compared with the general population, or both. A fitting parable for this situation can be seen in the novella Chronicle of a Death Foretold, by Gabriel Garcia Marquez, ${ }^{12}$ one of the great storytellers of the last century. An entire town knew about an upcoming murder, including the victim, who might have been innocent. The story takes many turns, but despite everyone's best intentions, moves inexorably toward the fatal outcome. The key sentence is, "It emerges that virtually everyone in town knew Santiago Nasar was to be murdered, who would do it, where, when and why. Given so much foreknowledge, the mystery is how the murder could have happened [sic]." 13 And so it is with patients with HLHS, who, despite the best efforts of everyone in the HLHS community, inexorably move toward their fate. Although this view may be seen as too fatalistic or pessimistic, it reflects the reality lived by these patients. I do not want to end on such a negative note, however, lest I discourage younger colleagues from pursuing the needed work and research in this field. Thirty years ago, none of these patients would have survived infancy, and that is something to celebrate. Nevertheless, the current state of affairs for HLHS, as summarized expertly by Karamlou and colleagues, ${ }^{1}$ is not acceptable, and we must be mindful to keep pushing the science and innovation to provide survivors with the best quality of life possible.

\section{References}

1. Karamlou T, Meza JM, Najm HK, Nigro JJ, Hill KD. Single-ventricle reconstruction 2.0: a closer look at our understanding of care for infants undergoing the Norwood procedure. J Thorac Cardiovasc Surg. 2019;158:837-42.e5.

2. Newburger JW, Sleeper LA, Gaynor JW, Hollenbeck-Pringle D, Frommelt PC, Li JS, et al; Pediatric Heart Network Investigators. Transplant-free survival and interventions at 6 years in the SVR trial. Circulation. 2018;137:2246-53.

3. Liu MY, Zielonka B, Snarr BS, Zhang X, Gaynor JW, Rychik J. Longitudinal assessment of outcome from prenatal diagnosis through Fontan operation for over 500 fetuses with single ventricle-type congenital heart disease: the Philadelphia Fetus-to-Fontan Cohort Study. J Am Heart Assoc. 2018;7:e009145.

4. Atz AM, Zak V, Mahony L, Uzark K, D'agincourt N, Goldberg DJ, et al; Pediatric Heart Network Investigators. Longitudinal outcomes of patients with single ventricle after the Fontan procedure. J Am Coll Cardiol. 2017;69: 2735-44.

5. Wolf MJ, Lee EK, Nicolson SC, Pearson GD, Witte MK, Huckaby J, et al; Pediatric Heart Network Investigators. Rationale and methodology of a collaborative learning project in congenital cardiac care. Am Heart J. 2016;174:129-37.

6. Mahle WT, Nicolson SC, Hollenbeck-Pringle D, Gaies MG, Witte MK, Lee EK, et al; Pediatric Heart Network Investigators. Utilizing a collaborative learning model to promote early extubation following infant heart surgery. Pediatr Crit Care Med. 2016;17:939-47.

7. Carlo WF, Cnota JF, Dabal RJ, Anderson JB. Practice trends over time in the care of infants with hypoplastic left heart syndrome: a report from the National Pediatric Cardiology Quality Improvement Collaborative. Congenit Heart Dis. 2017; 12:315-21.

8. Nathan M, Jacobs ML, Gaynor JW, Newburger JW, Dunbar Masterson C, Lambert LM, et al; Pediatric Heart Network Investigators. Completeness and accuracy of local clinical registry data for children undergoing heart surgery. Ann Thorac Surg. 2017;103:629-36.

9. Anderson BR, Kumar SR, Gottlieb-Sen D, Liava'a MH, Hill KD, Jacobs JP, et al; Congenital Heart Technical Skill Study. The congenital heart technical Skill Study: rationale and design. World J Pediatr Congenit Heart Surg. 2019;10: 137-44.

10. Gajarski RJ, Towbin JA, Garson A Jr. Fontan palliation versus heart transplantation: a comparison of charges. Am Heart J. 1996;131:1169-74.

11. Backer C. Presidential address. Presented at: Congenital Heart Surgeons Society 47th Annual Meeting; October 27-28, 2018; Chicago, Ill.

12. Garcia Marquez G. Chronicle of a Death Foretold. Rabassa G, trans. New York: Alfred A. Knopf; 1982.

13. Michaels L. Murder most foul and comic. New York Times. March 27, 1983; Late City Final Edition: sect 7:1. 